Article

\title{
Music and Spirituality: Reflections from a Western Christian Perspective
}

\section{Paul Westermeyer}

Emeritus Professor of Church Music, Luther Seminary, 2481 Como Ave, St. Paul, MN 55108, USA; E-Mail: pwesterm@luthersem.edu; Tel.: +1-651-644-3865

Received: 1 October 2013; in revised form: 6 November 2013 / Accepted: 7 November 2013 / Published: 13 November 2013

\begin{abstract}
Music and spirituality in a Christian view start with faith in the Word of God in response to the initiative of God who, as personal being through the Word revealed in Christ, seeks out persons even when they do not seek God. This mystery finds its goal in what is beyond expression in music from a variety of musical styles and syntaxes, from various times and places, in praise and prayer, and in relation to all of life. Matters like memory, health, emotion, time, silence, and community are involved. Paradoxes and a dark side are noted.
\end{abstract}

Keywords: Word of God; vocalization; jubilus; chant; proclamation; praise; prayer; text; tune; beauty

\section{Double Paradox}

Anthony Ruff begins a book on sacred music with the assertion that music is powerful ([1], p. 4). Quoting Edward Foley that "from time immemorial, the belief has persisted that music contains power to alter the moods and actions of gods and people” [2], he notes that philosophers have attributed powers and ethical influences to certain modes and that modern empirical evidence has gauged the physiological effects of music. Susan Palo Cherwien has delineated some of these ([3], p. 3-8). Ruff wonders if "our reactions to music are "innate or learned" ([1], p. 5) and quotes Nicholas Wolterstorff who, though some might challenge his assessment as he works with a larger swath of aesthetic stimuli, says that "the extent of intercultural agreement on these matters is astonishing" [4]. Ruff continues by pointing to music's communicative, communal, and ritual character. If only one of these characteristics were true, music and spirituality would still be connected; with all four it is no wonder that the 
connection has been so common. This does not make the connection easy to define. As John Bowden says, "That de facto [music] has a place [in relation to spirituality] may be hard to dispute; to define that place more closely verges on the impossible" [5]. This article is one person's tiny vignette about what verges on the impossible.

For the Christian church, the connection has been especially interesting because, in the Christian vision, God creates and addresses humanity. Music's power and other capacities live with the rest of the creation under God, not as magic controls in human hands. The connection is still more interesting because it involves a double paradox. The dictionary defines "spirituality" as relating to the immaterial and incorporeal as opposed to the material and physical. Christians who confess God as spirit and taking flesh in Christ embrace both the immaterial and the material. Music itself comprehends the same embrace: what is perceived as intangible or immaterial sound consists of physical vibrations heard through material bodies that pulsate. This double paradox lies at the heart of music and spirituality for Christianity. Susan Palo Cherwien summarizes it when she says that "singing hymns to worship God . . . unites body with spirit” [6].

\section{Sorting Things Out}

\subsection{Word of God}

Louis Bouyer in his Introduction to Spirituality helpfully leads into our topic. He explains how Christian spirituality is not a ratiocinative set of logical judgments by which one figures out paradoxes like this any more than it "drowns in sentimental musing" [7]. Christian spirituality, he says, is the "awareness of a spiritual reality ... that goes beyond the consciousness of the individual” ([7], p. 4), that realizes God is revealed in the person of Christ ([7], p. 6), and that starts with faith in the Word of God ([7], p. 7) in response to the "gratuitous, free, sovereign initiative of God" who seeks us even when we do not seek God ([7], p. 9).

\subsection{Musical Outcome}

Bouyer then explains the musical outcome. God as personal being par excellence addresses human beings ([7], p. 5) in the way one becomes a person, through speech ([7], p. 8). The divine Word of the Bible, definitively proclaimed and enfleshed in Christ, continues through the Spirit as the living Word of God in Christ's body the church into which the believer is incorporated ([7], pp. 8-13). This Word of God is proclaimed in the church in "a succession of living experiences" ([7], p. 33) through its reading and hearing. These call for "sacred song" in celebration, adoration and proclamation in the world to the glory of God ([7], p. 41). Every meditation of the Word and every contemplation of this Mystery "finds its goal in what is beyond expression."

The "jubilus" - that is, the musical vocalization of the "a" of the Alleluia - this, and this alone, can finally translate the ecstasy of the believing soul in the face of revealed truth, truth which is ultimately not an idea but a Person. ... ([7], p. 43). Faith in this Word, which leads to its musical vocalization, is neither a cold judgment nor the expression of artificially elaborated sentiments. It is the exultation of our whole being, ravished in the contemplation of the Mystery discovered in the Word ... which is essentially the gift of God [as the one] Who gives [and] is given ([7], p. 42). 


\subsection{Common Themes}

Bouyer's is a "catholic" posture, but God as person (in the Christian vision a Trinity of three persons) who addresses human persons through the Word is a theme that accompanies virtually all Christian streams. In Philip Pfatteicher's words, "Spirituality is, first of all, always a response" [8]. Though there are minority reports, the musical outcome in celebration, adoration, and proclamation is also ubiquitous and helps to understand why the church has so consistently sung Psalms and Canticles, what stands behind Colossians 3:16 ("Let the word of Christ dwell in you richly; teach and admonish one another in all wisdom; and with gratitude in your hearts sing psalms, hymns, and spiritual songs to God."), why the service of the Word has generated such a hymnic feast, why the celebration of the Lord's Supper has exploded into the singing of the Sanctus ("Holy, holy, holy . . . blessed is the one who come in the name of the Lord"), and why the earliest singers in the church were lectors who sang the readings [9].

\subsection{Words and Music}

It immediately becomes apparent that words that bear the Word of God are of central importance. Augustine defined a hymn as praise to God that is sung. Such singing of words about the Word ties words and music together closely. For Martin Luther it means music is next to the Word of God. Luther sensed that music is from the

sphere of miraculous audible things - like the Gospel [and] is a unique gift of God's creation [that] comes to us in the same way the Word of God does, namely, mediated by the voice [10].

Because of this close relationship between words and music [11], their distinction can be missed so that the meaning of words can be construed as if it were music. Poetry, of course, is musical or proto-musical or may even be called music because of its mellifluous ordering of sounds in time, but what we are dealing with here as music is the crafting and limiting of the vast raw material of creation's many sounds into forms that have the elements of specific rhythms, pitches, and tone colors, with or without texts. If the distinction between words and music is not observed, half of our topic is obliterated.

Jonathan Linman helps to avoid this confusion by noting what belongs to music in its intimate association with spirituality. Quoting the ancient saying, attributed to Augustine, "The one who sings prays twice" (sometimes given as "The one who sings well prays twice" or "Whoever sings [to God in worship] prays twice" [12]), he notes that music deepens the life of prayer as the "embodied qualities of music making carry the Word into ourselves and employ multiple dimensions of our physicality and experience.” Music “involves memory” as it links “certain texts and tunes.” By means of various styles music "can carry us in our imaginations and experiences to the ends of the earth such that we grow in appreciation for the gift of cultural diversity" and grasp a "sense of the rich tapestry [of the] human family” [13]. To Bouyer's celebration, adoration, and proclamation we can now add Linman's prayer, memory, and a communal tapestry related to the whole human family. 


\subsection{Music and Proclamation}

Luther emphasized the first cluster: celebration, adoration, and proclamation. He saw music as a gift of God ([14], pp. 321, 324) that proclaims the Word of God [15]. Once people know what God has done for them in Christ, said Luther, they "must gladly and willingly sing” [16]. God's gift of language combined with song was given so that we "should praise God . . . by proclaiming the [Word of God] through music” ([14], p. 323). Here praise, proclamation, celebration, and adoration all run together on a musical circuit of sound. What is perceived as incorporeal sound takes flesh in vibrating human bodies. They praise and adore the unseen God enfleshed in Christ as the Holy Spirit impels the singing of words that carry the Word of God by and through Christ's body the church. Walter Brueggemann adds another aspect of praise, a potent one. He says that

in the liturgy . . . the praise of Israel - or more broadly the human vocation of praise - is to maintain and transform the world, [that it is] world-making . . . through human activity which God has authorized and in which God is known to be present [17].

\subsection{Music and Prayer}

The embodied characteristic of music is also present when prayer is emphasized. Augustine, if he is responsible for "The one who sings prays twice," pointed there to the embodied deepening. So did John Calvin, who, like Luther, thought that singing was "peculiarly created to tell and proclaim the praise of God," but saw its chief use tied to public prayer in the assembly of believers [18]. Following Paul in Colossians 3:16, he regarded music as mutually edifying. When tempered to a fitting gravity he perceived it not only as lending "dignity and grace to sacred actions," but as having "the greatest value in kindling our hearts to a true zeal and eagerness to pray” [19]. John and Charles Wesley pointed in the same direction. As Carlton Young says, they "paraphrased the religion of the heart into song” [20]. S T Kimbrough identified "this union of music and poetry as Lyrical theology”" [20].

\subsection{Memory, Health, Emotion, and Time}

Memory, as Linman says, links texts and tunes. A certain melody recalls a certain text because the two were associated at some point, perhaps a critical one, in a person's life. Melodies also relate for many faithful churchgoers to Christian themes as in the church's liturgical year-some to Advent, others to Christmas (Christmas carols are the most obvious example), or Epiphany, Lent, Easter, and Pentecost.

Music bears a relation to memory in other ways. When members of a church visit an old person who can hardly speak, they may be surprised if they start a hymn and find the person singing it with them as if wholeness were suddenly restored [21]. Health is involved here ([3], pp. 9-12), not only for individuals but also for assemblies of believers [22]. Hearty congregational song is a sign of a healthy people. So is healthy emotion, to which music also relates.

The emotional piece is a tricky one because virtually every musical venue in our period ties music almost exclusively to emotion, often in superficial ways. The two are related, as Leonard Meyer has shown [23], or, as Don and Emily Saliers say, 
Because music is so close to human emotion and feeling, and, because faith is a matter of both the head and the heart, it leads us again and again into the realm of spirituality ([24], p. 17).

Meyer's and Saliers' insights need thoughtful consideration. (Their thought is more careful than much pervasive superficial talk about this topic.) However, one of the greatest twentieth century composers, Igor Stravinsky, also deserves thoughtful consideration and gives us pause about the unquestioned presupposition that links music with emotions. Stravinsky said that music was "essentially powerless to express anything at all, whether a feeling, an attitude of mind, a psychological mood, a phenomenon of nature, etc. . . ” ([25], p. 53). He thought it was a "misunderstanding” to search in music for "something that is not there” ([25], p. 162) and that looking in music for "emotions such as joy, grief, sadness, an image of nature, a subject for daydreams, orstill better-oblivion from 'everyday life”” is searching for "a drug_-dope”” ([25], p. 162-63). For Stravinsky music's ability to express something is "an illusion and not reality” ([25], p. 53). His central point has to do with humanity and time:

The phenomenon of music is given to us with the sole purpose of establishing an order in things, including, and particularly, the coordination between man and time. To be put into practice, its indispensable and single requirement is construction. Construction once completed, this order has been attained, and there is nothing more to be said ([25], p. 54).

What we see here are two spiritualities in relation to music. One emphasizes emotion; the other emphasizes music's relationship to time. This becomes more obvious when music without text is considered.

In the centuries following the New Testament, the church excised musical instruments from its assemblies because of instruments' association with idolatry and immorality [26-28]. That decision still stands in the Eastern Orthodox Church and points to the centrality of texted music sung by congregations and choirs. In the Western Church, the decision stood for the first millennium. After that organs and then other instruments were welcomed. Reformed communities in the sixteenth century and for several centuries thereafter reinstated the restriction, adding choirs to it. They largely have now embraced instruments and choirs with most of the Western church.

What then is happening when instruments play music without voices singing texts? If the music is built on a tune associated with a text like a hymn, the text will be referenced in the memory bank. If there are or are not such associations, whether music involves texts or not, it relates to time and to the time of worship as I explain in The Heart of the Matter.

... music spins itself out in time just the same as worship does. Music accompanies processions [as] the processional nature of the pilgrim people on the move takes place in time. Music articulates that time. . . Beyond that music articulates worship itself [in the] pace and shape and flow of a service [29].

That is, music articulates worship in relation to human life in time. That is why we sing the Psalms, which are about all of life's heights and depths before God. As Don and Emily Saliers comment,

Music is the temporal art par excellence . . . music is by its very nature ephemeral. It sounds within a now that vanishes. Our present moments are fleeting. Yet music mysteriously connects the time past with the now 
and with what is to come ... The very flow of life is given back to us in music that can touch that deeply in our bodies and souls ([24], p. 54).

\subsection{Community}

The historic sense of Christianity about spirituality and music is communal. The Christian understanding of God is Trinitarian. God's being as three-in-one is communal: "Father, Son, and Spirit are persons whose communal life is God," says Robert Jenson ([30], p. 226). In his view "God is beauty. ... A And the harmony of discourse taken for itself is its beauty; more precisely, its music” ([30], p. 234). God, says Jenson, "is a great fugue. There is nothing so capacious as a fugue” ([30], p. 236). That is, God is "roomy," and can decide to make room for others. "The opening of that room is the act of creation” ([30], p. 226) in which human beings are

taken into the triune singing . . . as the proclamation and prayer of the church regularly bursts into beauty. . . A congregation singing a hymn of praise to the Father is doubling the Son's praise, and the surge of rhythm and melody is the surge of the Spirit's glorification of the Father and the Son ([30], p. 235).

This community of God's very being which expresses itself in creation yields the community of the body of Christ that sings together. Individuals and their songs always exist in connection with the whole. As Bouyer points out, even the anchoritic monk needs and gravitates to the community ([7], pp. 207-10). The same is true for any solitary Christians, whether monks or not. Spirituality can clearly be separated from its Christian sense as among those who say, "I'm spiritual but not Christian [or] not religious [or] not related to a religious institution," but this is a civil religious or "common syncretistic” [31] instinct and not a Christian one.

As to the music that an individual or the community uses, its essence is what living believers sing. Something recorded and therefore frozen is not living. It is a dead artifact. Its use by individuals or even groups as they work or run or play may have a certain spirituality attached to it, but the essence of Christian song is alive with all the imperfections of life lived in time. In addition, the music that the individual or the community uses cannot be dependent on technology where, to quote Joseph Swain, microphone and amplifier have become "weapons of mass destruction”([32], p. 57). Worship is primal and requires living people who sing, not the "deadening" of "forced spontaneity" ([32], p. 166).

Community is also related to Linman's realization that various styles of music can lead us beyond our parochial times and places to appreciate the "rich tapestry [of the] human family" ([13], p. 66). For this leading to work out with constructive integrity, longstanding parochial expressions cannot be denied. That denial brings with it a denial of one's own identity. The song of the believers' time and place has to be affirmed along with the song of the other believers' times and places into a new song that brings the other two new songs in Christ ("new" here does not mean literally new, though it may encompass that meaning [33]) into collaborative interplay, just as neighborly relationships always do.

The danger of "spiritual tourism" has to be acknowledged and avoided in this encounter. Christopher Pramuk says, "Rather than probing the roots of our own spiritual or cultural malaise," using other spiritualities and their outcomes can too easily become a "self-centered way to retrieve something of our own lost innocence” in which "we as outsiders control or selectively plunder" another culture without inviting “our transformation and conversion” [34]. 


\subsection{Beyond Human Expression}

The embodying character, which paradoxically in Bouyer's words "finds its goal in what is beyond expression," moves from human sound to beyond the human trajectory. George Herbert says of church music,

But if I travel in your company, You know the way to heavens doore [35].

And Joseph Gelineau says that "in the celebration of the church's worship the point at issue is not 'music-making,' but entry by means of the art of music, into the salvific mystery” which "only by its beauty can signify the sacred” ([36], p.10). Beauty, as with Jenson, enters this conversation too. It is a characteristic of the documents on which Gelineau relies, among them the motu proprio, Tra le sollecitudini, of Pius X in 1903. Pius, like Calvin, says music is for the glory of God and the edification of the faithful, but adds this:

It helps to increase the beauty and splendor of the ceremonies of the Church, and since its chief duty is to clothe the liturgical text, which is presented to the understanding of the faithful, with suitable melody, its object is to make the text more efficacious, so that the faithful through this means may be more roused to devotion, and better disposed to gather to themselves the fruits of grace which come from the celebration of the sacred mysteries [37].

When Francis Williamson sought to understand such descriptions, he analyzed them like this.

The phrase, "to enhance the word" [clothe the liturgical text], is not to interpret the word in a meaningful sense so much as to clothe the word with beauty and sacral character. Ultimately even this word becomes mute because it is secondary to the act of sacrifice and communion. The climax of adoration in the Presence is silence, symbolic of final peace [38].

Or, in Gelineau's words,

Music can never reveal to us the whole of its mystery until it has become silent and no more sounds reach our ears. For the praise of heaven, pure love, will have no further need for the art of sound ([36], p. 27).

Not all Christians see music moving to silent music as pure love or peace. I heard Walter Bouman on more than one occasion say that in the praise of heaven there will be no need for preaching, but there will be song. Christopher Page suggests that Tertullian, Irenaeus, and Saint John would concur, that while

the baser functions of the body will pass away in the blessed state, the higher ones will remain. . In contrast to labour with the hands, eating, drinking, and the exertions of coitus, the use of the voice is one of the principal continuities between the states of bodily life on either side of the grave ([9], p. 49).

\subsection{Silence}

Silence enters this discussion not only as music's end, but as its beginning. Augustine can be understood to view the music we hear as coming from a spiritual model, from the music of silence [39]. Joseph Ratzinger, before he became Pope Benedict XVI, in a discussion relying on Philipp Harnoncourt [40], said this: 
Faith comes from listening to God's word. But wherever God's word is translated into human words there remains a surplus of the unspoken and unspeakable which calls us to silence - into a silence that in the end lets the unspeakable become song and also calls on all the voices of the cosmos for help so that the unspoken may become audible. This means that church music, coming from the Word and the silence perceived in it, always presupposes a new listening to the whole richness of the Logos [41].

\subsection{The Absence of Music}

Silence can be construed less positively as the avoidance or absence of music because music and spirituality are seen as unrelated or not positively related. The monk Pambo is reported to have seen no contrition in singing and to have compared it to the lowing of cattle [42]. Ulrich Zwingli, though the best musician of the sixteenth century reformers, thought the true song was to be found in "our hearts" and that music in church was "mumbling and murmuring" [43]. For him, the paradox of music and spirituality does not exist because "material things could not participate in the holy [since] Spirit and flesh contradict each other" [44]. Zwingli removed music from the church altogether so that silence would give people an ear for the Word of God alone-that is, without music, and he tied music to play (which may be perceived as its own form of spirituality). Anabaptists made the same move [45]. English Baptists like John Smyth also shut out music from worship unless it was improvised on the spot because they asked, "Whither meter, Rithme, \& tune, be not quenching the Spirit” [46]. Benjamin Keach at first agreed, but changed his mind and "repaired the breach" for Baptists [47]. Quakers have centered down to the inner light where they find that in holy silence seen as "Holy Obedience" they come upon God [48].

Hildegard of Bingen, who thought "all creation is a single hymn in praise of God" [49], strongly reversed the notion of the absence of music as a good thing. For her, the paradoxes posed by music and spirituality are alive and well. When an interdict on singing was issued against her community, she said this:

And I heard a voice coming from the Living Light concerning the various kinds of praises, about which David speaks in the psalm . . . "Let every spirit praise the Lord” (Ps. 150:3, 6). These words are outward, visible things to teach us about inward things. Thus the material composition and the quality of these instruments instruct us how we ought to give form to the praise of the Creator and turn all the convictions of our inner being to the same ([50], pp. 81-82).

She objected strenuously to the interdict because she regarded the absence of music as the devil's work. It is the devil who

never ceases from confounding confession and the sweet beauty of both divine praise and spiritual hymns, eradicating them through wicked suggestions, impure thoughts, or various distractions from the heart of man and even from the mouth of the Church itself, wherever he can, through dissension, scandal, or unjust oppression ([50], p. 83). So she instructed the prelates to exercise the greatest vigilance to clear the air by full and thorough discussion of the justification for such actions before your verdict closes the mouths of any church singing praises to God ... ([50], p. 83).

It is no accident that in her morality play Ordo Virtutum, in a "clear contrast with the musicality of the Virtues," it is only 
the Devil [who] cannot sing; he can barely speak mellifluously. The Ordo calls for the Devil to speak in a voice that is strepitus (grating, shouting, growling) ([50], p. 110).

\subsection{The Dark Side}

Augustine delighted in the sound of music but knew it could be an idolatrous form of gratifying the flesh if it overtook the meaning of the words that were being sung. He vacillated between its value and its danger, finally endorsing its use as long as the text was not obscured [51]. Luther knew that music, the "gift of nature and art," could be "prostituted" by "perverted minds . . . with their erotic rantings” ([14], p. 324). Calvin was especially cognizant of music's danger and thought music tied to bad words distilled "venom and corruption ... to the depths of the heart" [52].

Anne Morris notes that ethical and theological cautions of this sort have largely been forgotten [53]. Though she realizes that "music can undoubtedly be a force for good," she is acutely aware that “we ignore music’s potential for harm at our peril” ([54], p. 204). She presents three case studies, the first about music used to affect emotion at a funeral, the second about music used for propaganda in the Third Reich, and the third about music used as an instrument of "no-touch torture" ([54], pp. 205-15). In all three cases music does not grow out of an interior spiritual center but is imposed from the outside as a tool of control.

In many of its current societal manifestations music is regarded as an emotional manipulator. Morris speaks with a voice of historic Christian concern in a context where music is often identified with the culture's commercial presupposition that music is a way to sell things, attract people, and keep institutions afloat by amassing enough revenue.

Parts of the church have bought into this perspective and have engaged in "worship wars" that have taught people to attack one another based on musical styles. This abrogates the first commandment by focusing on musical idols, not on God. It is not the way Christians have historically understood God, nor the way many churches still today understand God, as in every generation they stand against the culture. The church, when it follows the culture's use of music as a tool to sell things, relates music to words like "evangelism" and "mission" which, for all the good that may be intended, are often euphemisms for the power, control, and manipulation that Morris addresses. Spirituality in Bouyer's historic Christian sense is not at issue here and may also help to explain why people like C. S. Lewis in an earlier time regarded hymns as the gang songs of the church [55].

\subsection{Musical Styles and Syntax}

The musical outcome of spirituality to which Bouyer points is not the vocalization on the "a" of the Alleluia in a theoretical sense. That it takes sounding form means it takes form in actual musical styles and syntaxes. Various spiritualities lead not to one style or syntax, but to multiple ones. Here are a few thoughts about that.

\subsubsection{Praise and proclamation}

The exuberant leaps in Hildegard's music express her spirituality of praise and proclamation. So does the exuberant proclamatory punch at the beginnings of phrases in the chorales spawned by Luther's reforms, responding to the thrust of the Word of God that addresses humanity. 


\subsubsection{Prayer}

Pius $\mathrm{X}$ in his motu proprio sees Gregorian chant and the polyphony of Palestrina as ideals [56]. Gelineau follows with "Gelineau psalmody" [57]. Gelineau introduced the Taizé community to Jacques Berthier "as someone who could compose short repetitive songs that have become famous as 'Taizé music”” [58]. These are all examples of music related to prayer via forms of chant.

Calvin in sixteenth century Geneva spawned Genevan psalm tunes composed by Louis Bourgeois. Calvin regarded chant as a foreign tongue, so it was off limits as were choirs and instruments. Tunes for metrical psalms were the music of choice.

While chant and Genevan psalm tunes may not appear to have very much in common, they both have pulls from the ends of the musical lines that respond to the teleological tug of prayer and contrast with the prophetic push at the beginning of chorales. Genevan psalm tunes also distinguish themselves from chorale tunes in that they have short notes nestled between long ones in conjunct motion. The cyclical, repetitive forms from Taizé add a timeless component. (See the next point.)

\subsubsection{Community}

When community is emphasized a rich supply of syntaxes is employed as "global" music from Latin America, Asia, South Africa, Zimbabwe, and the Iona Community [59]—along with black spirituals, shape note music, and European models-comes together in American "mainstream" practice. The global repertory opens congregations to spiritualities that stand outside of their own and helps them avoid the idolatry that can so easily beset groups that live to themselves. As Michael Hawn says, it can be liberating. It also poses a different spirituality from much Western "mainstream" practice. A “classic Western hymn,” even with a tune that repeats, is narrative, "going somewhere” ([59], p. 225). Global cyclic structures engage congregations in a “more timeless experience” ([59], p. 234).

\subsubsection{An Anglican Perspective}

\section{Alastair Cassels-Brown says that}

The link between music and Anglican spirituality . . . is simple: Anglican spirituality is rooted in the Church's liturgical life. Liturgical music serves two purposes; it is an offering of praise in the context of the liturgy and it enhances the liturgy ([60], p. 121).

He points out that the music of the Anglican Church is varied and-in a concentrated way representative of the whole church, though he does not say that-moves from simple congregational settings for parishes to elaborate choral anthems for cathedrals ([60], p. 121).

While the link between Anglican spirituality and music may be simple in theory, it quickly becomes obvious that it is complex in practice as differences of opinion about how to point Anglican chant are discussed ([60], pp. 121-25), as four high and higher purposes of the music are defined: from keeping a congregation together to raising "people's spirits to a new level—poetical or mystical—because its wings carry us up into timelessness” ([60], p. 125), as hymnody is seen to be eclectic ([60], pp. 126-27), and as music that is "sensuous and pseudoromantic" is not regarded as "bringing devotion to the devout" or "satisfying an uplifting experience" ([60], p. 131). 


\subsubsection{Laudi Spirituali}

Popular non-liturgical Italian spiritual lauds in the Middle Ages and Renaissance are best characterized as devotional, stemming from the praise of Francis of Assisi's "Canticle of the Sun" in the early thirteenth century, and related to works of mercy, missionary endeavors, and penitence. Dean L. Root says that "profane songs were to be replaced by godly ones." Their themes were "the Virgin, the birth, Passion and Resurrection of Christ, the saints, including St. Francis, the Holy Spirit, The Divine Love and the approach of death." He describes them musically as "related to the Italian ballata, the French virelai and the English carol," with small range, conjunct motion, in major keys, monophonic, and syllabic ([61], p. 537). Deciding what their rhythm may have been is, as usual, “problematic" ([61], p. 540). They proceeded in semi-professional, professional, polyphonic, homophonic, and macaronic directions, sometimes with instruments and accompanying dance, and with influences on plays and the development of the oratorio [62].

\subsubsection{An Afro-American Perspective}

The "American Dilemma” [63] of blacks in a white culture, with the underlying horrors of slavery and all the inequities and injustices of an evil system, paradoxically as perhaps with all oppression, created remarkable music, in this case the African American spiritual and the musical results like jazz that it spawned. Beginning as a congregational medium in praise houses away from the master's house, this music combined African and American syntaxes in "a wild, weird, plaintive, sad, and sorrowful" beauty ([64], p. 44) with double meanings that "expressed the faith of the people, but also provided signals for the time and place of the next 'underground railroad train' which could lead them out of bondage into freedom" ([64], p. 45). More than that, the music contained what Theophus H. Smith calls “style-switching," a term he borrows from the social linguist Morton Marks ([65], pp. 387-88). He calls this both black and white, European and African, and refers to W.E.B. Dubois' "double consciousness." "The change in style," he says, "is generating a ritual event, namely spirit possession," with "trance-associated features" and "signals of transcendence" ([65], p. 388).

Smith notes "two other aspects of black music that convey spiritual dynamics: call-and-response [which he also calls antiphony] and improvisation” ([65], p. 389). These, he says, in their participatory character, created "sustained drama and spiritual intensity" with a "state of high religious ecstasy" ([65], p. 389). And they in turn led to "matters of theory and practice” ([65], p. 390). That is, the great black musicians like Louis Armstrong and "Duke" Ellington in their playing by ear found the score "inadequate for their purposes . . . Crucial for black spirituality in its aesthetic manifestations is this ‘will to transformation'” ([65], p. 391).

\subsubsection{Lament}

The Psalms of the Old Testament, which undergird Christian singing are full of laments, and the word "psalm" itself means a "song sung to the harp." The priestly class of Temple singers called Levites were likely deputed in part to sing laments ([66], p. 105), and the functions of the vocalizations related to laments all have resonant musical or proto-musical characteristics: to call or raise the voice, to cry, to groan or scream or moan, to shout and yell, and to cry for help ([67], pp. 16-18). However, 
for Israel, whose spirituality informs Christian spirituality, "life (meaning life in its fullness) . . . is virtually synonymous with praise” ([68], p. 6), laments move to praise ([68], pp. 2, 7, and throughout), and lament has the capacity to strike one dumb ([68], p. 177). This means the musical outcome of lament can be both wild and muted.

When one deals with spirituality and music, therefore, it is probably not surprising that lament is not front-and-center. It is there, to be sure, but always pressing with less than ordered proto-musical wails or just under the surface with quietly repressed sobs. It finds ordered liturgical communal and individual expression as a people lives through its horrors and gives shape and meaning to them in the light of God's grace which drives to praise.

\subsubsection{Music after the Second Vatican Council in the Twentieth Century}

The Second Vatican Council affirmed the same ideals (chant and Palestrina) that Pius X affirmed, but it also, along with many Protestant bodies, affirmed a move toward enculturation-a move that included the vernacular instead of Latin and with vernacular popular musical styles. This set in motion a dispute within the Roman Catholic Church which has yet to be resolved [69] and which has been and still is being played out in parallel forms across Protestant churches.

At its best, this dispute has not been a dispute, but has yielded a wide musical feast of old and new (or what may seem both old and new) in which congregations and choirs sing a remarkably wide range of styles that grow out of a potently ecumenical and "catholic" spirituality. It stands before God, revels in the kaleidoscopic richness of the church's heritage, and lets Word and sacraments lead musically where they will. Congregations with this perspective often sing around Word, font, and table together in one single weekly Sunday gathering like the Eastern Orthodox Church. There are exceptions where congregations sponsor multiple services in different styles, but still live together in peace toward the world they are called to serve.

At its worst, this dispute has bitterly pitted congregations against themselves and against one another in "traditional" and "alternative" services. In Roman Catholic versions, Latin masses with Gregorian chant are lined up against vernacular ones in "popular” musical styles with arguments about the validity of hymns. In Protestant versions, "traditional” musical styles are set against "popular” ones with the curiosities that some "alternative" services are more "traditional" in their structures than "traditional” ones, and that none of the music called "contemporary” employs tone clusters, aleatory or twelve tone techniques, or similar contemporary characteristics. Warring spiritualities may be seen to drive this dispute, but they sometimes, in Morris's words, seem to have travelled to the dark side, abandoning spirituality altogether.

\subsection{Spirituality and Musicians}

A note needs to be included about musicians themselves. Christopher Page points to the "spirituality and erudition a ninth century cantor might possess" (including hospitality in that context) ([9], pp. 352-53). Timothy Tikker has discussed organ playing as a spiritual discipline [70], and Luther Seminary MSM student Andrew Birling played “An Organist’s Evensong,” which was a profoundly congregational service while at the same time highlighting the organist's spirituality. The cover of Birling's program gave a visual cue. It printed the painting "Evensong” by the nineteenth 
century painter John Melhuish Strudwick, which pictures an organ, organist, and singers in the church making music at Evensong [71]. Some of the most profound spirituality has been exhibited by church musicians throughout the church's history in connection with their musical craft and its practice.

Its practice has included composition-much of it. As Swain says, "For centuries now the church has owned a repertory of masterworks that is by far the greatest of any institution, nation, people, or religion in the world” ([32], p. 6). That repertory includes the exquisite ethereal craft of Palestrina, the cantatas of J.S. Bach whom Robert Shaw said may be the "single greatest creative genius" of the Western world [72], the B Minor Mass, which Shaw suggested may be Bach's "greatest achievement" [72], the music of the catholic mystic Olivier Messiaen, and in some accounts what stands alongside or outside the Christian stream, such as Franz Schubert's An die Musik, which Bowden ranks “among the world's greatest prayers of thanksgiving” ([5], p. 272).

Masterworks are not the only compositional part of the church's repertory. The congregational piece has little-known or anonymous composers of remarkable miniatures that include black spirituals, shape-note tunes, chorale tunes, Genevan psalm tunes, nineteenth century Anglican ones, chant tunes, service music, and a host of similar pieces in multiple styles from multiple ethnicities.

\section{Conclusion: Another Paradox}

The nature of the repertoire is not a simple matter, however. Though Johannes Brahms knew as much or more about the Bible than most clergy, and though Ralph Vaughan Williams edited The English Hymnal (1906) and wrote fine hymn tunes, these two are among the church's composers who regarded themselves as agnostics or atheists. In his German Requiem, Brahms included a potent setting of "But yet the Lord's word endureth forevermore," and Vaughan Williams compellingly set "O taste and see how gracious the Lord is; blest is the man that trusteth in him.” These are but two examples from many such pieces that the church loves and sings with faithful devotion in service music at worship and welcomes in oratorios. What are we to make of this? Is it possible for an authentic spirituality to be expressed in music by composers who presumably do not possess it?

Whether they possess it or not is a mystery. They may be put off by the church's hypocrisy, refuse therefore to express any spirituality publically, internally find it present, and express it in their music. That cannot be determined. It is a secret matter in the heart of the composer, conscious or unconscious. As far as the music itself is concerned, however, the question is irrelevant. The church decided long ago that Donatism is wrong and that the immorality, non-belief, heresy, or whatever of the clergy does not affect the truth of the Word they preach or the validity of the sacraments at which they preside. Similarly, spirituality or its absence in composers does not affect the validity of their compositions. Whether they secretly in their composing are making a confessional statement is also irrelevant. That is, spirituality in the Christian vision transcends human cognitive capacities, and what human beings compose takes on a life of its own apart from the intentions of the person who composed it.

\section{Conflicts of Interest}

The author declares no conflict of interest. 


\section{References and Notes}

1. Anthony Ruff. Sacred Music and Liturgical Reform: Treasures and Transformations. Chicago: Hillenbrand, 2007, pp. 4-5.

2. Edward Foley. "Music in Ritual: A Pre-Theological Investigation.” In American Essays in Liturgy 1. Washington: Pastoral Press, 1984, p. 2.

3. Susan Palo Cherwien. "That Spoke So Sweetly and So Well: Music and the Body, Music and the Mind, Music and the Spirit.” Mundelein College, Chicago, IL, 10 March 1991, pp. 3-12.

4. The quotation is from Nicholas Wolterstorff. Art in Action: Toward a Christian Aesthetic. Grand Rapids, MI: Eerdmans, 1987, p. 106.

5. John Bowden. "Music and Spirituality." In The Westminster Dictionary of Christian Spirituality. Edited by Gordon S. Wakefield. Philadelphia: Westminster, 1983, pp. 271-72.

6. Susan Palo Cherwien. "With Mind in Heart: Wholeness in Hymn Making." CrossAccent 13, no. 1 (2005): 22. Her paper "That Spoke So Sweetly and So Well” explores the topic in more depth.

7. Louis Bouyer. Introduction to Spirituality. New York: Desclee, 1961, pp. 4-43, 207-10.

8. $\quad$ Philip H. Pfatteicher. Liturgical Spirituality. Valley Forge, PA: Trinity International, 1997, p. 3.

9. Christopher Page. The Christian West and its Singers. New Haven, CT: Yale University Press, 2010.

10. Oskar Soehngen. "Fundamental Considerations for a Theology of Music.” In The Musical Heritage of the Church. Edited by Theodore Hoelty-Nickel. St. Louis: Concordia Publishing House, 1963, vol. 6, pp. 15-16.

11. For a careful study of music and language in relation to the brain, see Aniruddh D. Patel. Music, Language, and the Brain. New York: Oxford University Press, 2008.

12. Brian Wren. Praying Twice: The Words and Music of Congregational Song. Louisville: Westminster John Knox, 2000, p. 1.

13. Jonathan Linman. Holy Conversation: Spirituality for Worship. Minneapolis: Fortress, 2010, p. 66.

14. Martin Luther. "Preface to Georg Rhau's Symphoniae Iucundae." In Luther's Works. Philadelphia: Fortress, 1965, vol. 53, pp. 321-24.

15. Martin Luther. “Table Talk.” In Luther's Works. Philadelphia: Fortress, 1965, vol. 54, p. 129. For a fuller study of this topic, see Daniel Zager. The Gospel Preached Through Music: The Purpose and Practice of Lutheran Church Music. Fort Wayne: Concordia Theological Seminary Press, 2013. For additional background, see Carl Schalk. Luther on Music: Paradigms of Praise. St. Louis: Concordia Publishing House, 1988.

16. Martin Luther. "Preface to the Babst Hymnal.” In Luther's Works. Philadelphia: Fortress, 1965, vol. 53, p. 333.

17. Walter Brueggemann. Israel's Praise: Doxology against Idolatry and Ideology. Philadelphia: Fortress, 1989, p. 11.

18. John Calvin. Institutes of the Christian Religion. Edited by John T. McNeill. Philadelphia: Westminster, 1960, III, 31, p. 894.

19. John Calvin. Institutes of the Christian Religion. Edited by John T. McNeill. Philadelphia: Westminster, 1960, III, 32, p. 895. 
20. Carlton R. Young. Music of the Heart: John and Charles Wesley on Music and Musicians. Carol Stream, IL: Hope Publishing, 1995, p. 28.

21. For more about music and the brain see Daniel J. Levitin. This Is Your Brain on Music: The Science of a Human Obsession. New York: Dutton, 2006 and Oliver Sacks. Musicophilia: Tales of Music and the Brain. New York: Knopf, 2007, especially chapter 15 about music and amnesia.

22. See Paul Westermeyer. “To Be Human Is To Sing.” In The Luther Northwestern Story 7, Winter 1990, 48.

23. See Leonard B. Meyer. Emotion and Meaning in Music. Chicago: University of Chicago Press, 1956.

24. Don Saliers, and Emily Saliers. A Song to Sing, a Life to Live: Reflections on Music as Spiritual Practice. San Francisco: Jossey-Bass, 2005.

25. Igor Stravinsky. An Autobiography. New York: Norton, 1936, pp. 53-54, 162-63.

26. See James McKinnon. Music in Early Christian Literature. Cambridge: Cambridge University Press, 1987.

27. See Calvin R. Stapert. A New Song for an Old World: Musical Thought in the Early Church. Grand Rapids, MI: Eerdmans, 2007.

28. See Paul Westermeyer. Te Deum: The Church and Music. Minneapolis: Fortress, 1998, pp. 66-76.

29. Paul Westermeyer. The Heart of the Matter: Church Music as Praise, Prayer, Proclamation, Story, and Gift. Chicago: GIA Publications, 2001, p. 44.

30. Robert W. Jenson. Systematic Theology. Oxford: Oxford University Press, 1997, vol. 1, pp. 226-35.

31. Phrase supplied by Francis Williamson, e-mail to the author, 19 September 2013.

32. Joseph P. Swain. Sacred Treasure: Understanding Catholic Liturgical Music. Collegeville, MN: Liturgical Press, 2012.

33. See Paul Westermeyer. Rise, O Church: Reflections on the Church, Its Music, and Empire. St. Louis: MorningStar, 2008, p. 23.

34. Christopher Pramuk. “Silences.” Worship 87, no. 4 (2013): 365.

35. George Herbert. “Church-Musick.” In The Poems of George Herbert. London: Oxford University Press, 1961, p. 57.

36. Joseph Gelineau. Voices and Instruments in Christian Worship: Principles, Laws, Applications. Translated by Clifford Howell. Collegeville, MN: Liturgical Press, 1964.

37. Quoted in Robert Hayburn. Papal Legislation on Sacred Music 95 A.D. to 1977 A.D. Collegeville, MN: Liturgical Press, 1979, p. 224.

38. Francis Williamson. "The Lord's Song and the Ministry of the Church.” ThD diss., Union Theological Seminary, 1967, p. 261.

39. See Henri Davenson [Henri Iréneé Marrou]. Traité de las Musique selon l'Espirit de Saint Augustin. Neuchatel, Switzerland: Les Cahiers du Rhône, 1942, p. 17ff.

40. Philipp Harnoncourt. "Gesang und Musik im Gottesdienst." In Die Messe: Ein kirchenmusichalisches Handbuch. Edited by Harald Schützeichel. Düsseldorf: Patmos Verlag, 1991, pp. 2-45.

41. Joseph Cardinal Ratzinger. A New Song for the Lord: Faith in Christ and Liturgy Today. Translated by Martha M. Matesich. New York: Crossroad, 1996, p. 137. 
42. Johannes Quasten. Music and Worship in Pagan and Christian Antiquity. Translated by Boniface Ramsey. Washington, DC: National Association of Pastoral Musicians, 1983, p. 95.

43. Charles Garside. Zwingli and the Arts. New Haven, CT: Yale University Press, 1966, p. 45.

44. Bard Thompson. "Ulrich Zwingli." In Reformers in Profile: Advocates of Reform. Edited by Brian A. Gerrish. Philadelphia: Fortress, 1967, p. 128.

45. See John K. Harms. "Music of the Radical Reformation II.” Church Music 78, no. 1 (1978): 23.

46. John Smyth. "Certain demaundes from the auncyent brethren of the Separation.” In The Works of John Smyth. Cambridge: Cambridge University Press, 1915, vol. II, pp. 324-25.

47. See Benjamin Keach. The Breach Repair'd in God's Worship. London: Printed for the Author, 1691.

48. Elton Trueblood. The People Called Quakers. New York: Harper \& Row, 1966, p. 86.

49. Heinrich Schipperges. Hildegard of Bingen: Healing and the Nature of the Cosmos. Translated by John A. Broadwin. Princeton, NJ: Markus Weiner, 1997, p. 27.

50. Anne H. King-Lenzmeier. Hildegard of Bingen: An Integrated Vision. Collegeville, MN: Liturgical Press, 2001.

51. Augustine. Confessions. In Music in Early Christian Literature. Translated by James W. McKinnon. Cambridge: Cambridge University Press, 1987, pp. 154-55.

52. Charles Garside. “Calvin’s Preface to the Psalter: A Re-appraisal.” Musical Quarterly 37, no. 4 (1951): 570.

53. But not completely: "The music and the singing are as important as the words. When hymns are sung the theology is embodied. It is taken in, translated, interpreted, and transmitted. In the process singers are, perhaps physically and mentally, formed or changed. Not pushing the metaphor too far, is it any way like eating - what is eaten becomes part of us and can nourish or poison?" Andrew Pratt. "Hymns and the Nature of Evil Toward a Sung Theodicy: A Hymnwriter's Musings.” The Hymn 64, no. 2 (2013): 12.

54. Anne Morris. "Music in Worship: The Dark Side.” Practical Theology 3, no. 2 (2010): 204-15.

55. See Erik Routley. “Correspondence with an Anglican Who Dislikes Hymns.” The Presbyter 6, no. 2 (1948): 17.

56. For discussions of Gregorian chant see Willi Apel. Gregorian Chant. Bloomington: Indiana University Press, 1958 and David Hiley. Western Chant: A Handbook. Oxford: Clarendon Press, 1993.

57. See Joseph Gelineau. Psalmody in the Vernacular: The Theory and Application of the Gelineau Method of Psalmody. Toledo: GIA Publications, 1965.

58. Dirk G. Lange, e-mail to author, 7 June 2008.

59. See Michael Hawn. Gather into One: Praying and Singing Globally. Grand Rapids, MI: Eerdmans, 2003, pp. 225, 234.

60. Alastair Cassels-Brown. "Music as an Expression of Anglican Spirituality." In Anglican Spirituality. Edited by William J. Wolfe. Wilton, CT: Morehouse-Barlow, 1982, pp. 121-31.

61. Deane L. Root. “Lauda spirituale.” The New Grove Dictionary of Music and Musicians. Edited by Stanley Sadie. London: Macmillan, 1980, vol. 10, pp. 537-40. 
62. Root provides a good overview. See also J.A. Wayne Hellman. "The Spirituality of the Franciscans.” In Christian Spirituality: High Middle Ages and Reformation. Edited by Jill Rait, Bernard McGinn and John Meyendorff. New York: Crossroad, 1988, vol. 2, p. 36; and Richard Kieckhefer. “Major Currents in Late Medieval Devotion.” In Christian Spirituality. p. 77.

63. See Gunnar Myrdal. An American Dilemma. New York: McGraw-Hill, 1964, 2 vols.

64. Melva Wilson Costen. African American Christian Worship. Nashville: Abingdon, 1993.

65. Theophus H. Smith. "The Spirituality of Afro-American Traditions.” In Christian Spirituality: Post-Reformation and Modern. Edited by Louis Dupré and Don E. Saliers with John Meyendorff. New York: Crossroad, 1989, vol. 3, pp. 387-91.

66. Paul Wayne Ferris. The Genre of Communal Lament in the Bible and the Ancient Near East. Atlanta: Scholars Press, 1992.

67. Richard Nelson Boyce. The Cry to God in the Old Testament. Atlanta: Scholars Press, 1988.

68. Frederick J. Gaiser. “Songs in the Story.” Doctoral Dissertation, University of Heidelberg, 1984.

69. See Anthony Ruff. "After Vatican II: Are We All Protestants Now? Or Are We All Catholics Now?” CrossAccent 21, no. 2 (2013): 12-21.

70. Timothy Tikker. “Organ playing as spiritual discipline.” The American Organist 41, no. 6 (June, 2007): 72-75.

71. Andrew Birling. “An Organist’s Evensong: Music for the Ascension” at St. Paul's Episcopal Church in Minneapolis, MN, on May 11, 2013.

72. Robert Blocker. The Robert Shaw Reader. New Haven, CT: Yale University Press, 2004, p. 71.

(C) 2013 by the author; licensee MDPI, Basel, Switzerland. This article is an open access article distributed under the terms and conditions of the Creative Commons Attribution license (http://creativecommons.org/licenses/by/3.0/). 